Article

\title{
Life-Cycle Assessment of Alternative Envelope Construction for a New House in South-Western Europe: Embodied and Operational Magnitude
}

\author{
Helena Monteiro ${ }^{1,2, *(\mathbb{D})}$, Fausto Freire ${ }^{2}(\mathbb{D})$ and John E. Fernández ${ }^{3,4}$ \\ 1 Low Carbon \& Resource Efficiency, R\&Di, Instituto de Soldadura e Qualidade, 4415-491 Grijó, Portugal \\ 2 ADAI, Department of Mechanical Engineering, University of Coimbra, Rua Luís Reis Santos, \\ 3030-788 Coimbra, Portugal; fausto.freire@dem.uc.pt \\ 3 Building Technology Program, Department of Architecture, Massachusetts Institute of Technology, \\ 77 Massachusetts Avenue, Cambridge, MA 02139, USA; fernande@mit.edu \\ 4 Environmental Solutions Initiative, Massachusetts Institute of Technology, Cambridge, MA 02139, USA \\ * Correspondence: himonteiro@isq.pt; Tel.: +351-963-378-570
}

Received: 30 June 2020; Accepted: 6 August 2020; Published: 11 August 2020

\begin{abstract}
The building envelope is critical to reducing operational energy in residential buildings. Under moderate climates, as in South-Western Europe (Portugal), thermal operational energy may be substantially reduced with an adequate building envelope selection at the design stage; therefore, it is crucial to assess the trade-offs between operational and embodied impacts. In this work, the environmental influence of building envelope construction with varying thermal performance were assessed for a South-Western European house under two operational patterns using life-cycle assessment (LCA) methodology. Five insulation thickness levels $(0-12 \mathrm{~cm})$, four total ventilation levels (0.3-1.2 ac/h), three exterior wall alternatives (double brick, concrete, and wood walls), and six insulation materials were studied. Insulation thickness tipping-points were identified for alternative operational patterns and wall envelopes, considering six environmental impact categories. Life-cycle results show that, under a South-Western European climate, the embodied impacts represent twice the operational impact of a new Portuguese house. Insulation played an important role. However, increasing it beyond the tipping-point is counterproductive. Lowering ventilation levels and adopting wood walls reduced the house life-cycle impacts. Cork was the insulation material with the lowest impact. Thus, under a moderate climate, priority should be given to using LCA to select envelope solutions.
\end{abstract}

Keywords: LCA; environmental impact; house; building envelope; thermal performance

\section{Introduction}

Households represent around $27 \%$ of the European Union's (EU) final energy consumption. To address this, EU regulatory efforts have been enacted to promote energy efficiency, and the new EU Green Deal roadmap aims to encourage that EU building stock (new and existing buildings) become energy and resource efficient. To support new building developments, a life-cycle perspective is recommended since reducing operational energy through improved building envelopes is likely to affect the impact of other life-cycle phases of new buildings.

Life-cycle assessment (LCA) has been extensively used to study residential buildings [1,2], building options [3,4], and building construction [5]; however, most studies have focused on primary energy and/or $\mathrm{CO}_{2}$ emissions, disregarding other environmental impacts. Review articles on LCA of buildings [6,7] agree that comparing different studies is not linear because building characteristics (size, shape, construction, and occupation) vary with location and climate, and the studied methodological 
assumptions (functional unit, lifespan, life-cycle impacts, exclusions) widely vary [8,9]; although some trends can be climate specific, each study helps to explain a climatic and regional context.

Studies covering cold climate houses in developed countries have concluded that the operational phase has a preponderant weight in the total life-cycle of the building [1,10]. Moreover, studies of conventional buildings in different countries (Sweden [11], Kazakhstan [12], Alaska, USA [13], Spain [14], Portugal [15]) have showed that operational energy is dominant, representing $60-90 \%$ of the total environmental impacts. Thus, reducing heating and cooling is essential. Interestingly, a study that provided an LCA benchmark for dwellings in North Italy and Denmark [16] showed that, in North Italian case studies, operational impacts accounted for 69-76\%, and embodied impacts accounted for $24-31 \%$ of the overall impact, whereas in Danish cases, the impacts per life-cycle phase are reversed due to the low impact of the future Danish energy grid. This shows that life-cycle results are also highly sensitive to specific regional conditions other than climate, such as the energy mix.

Dylewski [17] studied the environmental impact of diverse thermal insulation materials for exterior walls in Poland, considering alternative heat sources, in order to find the optimal insulation thickness considering both economic and ecological net present value of insulation (as an investment). Results showed that significantly higher thicknesses were recommended when considering environmental data as compared to economic data-for instance, $0.46-0.52 \mathrm{~m}$ of expanded polystyrene (EPS) insulation considering brick walls and a heat pump system. Some LCA studies assessed low energy and passive houses [18-20], in which operational energy is substantially reduced. Generally, when operational energy is reduced, the relative contribution of embodied impact rises and therefore a life-cycle perspective is essential [21].

In low energy houses, embodied energy can amount to $50-70 \%$ of the life-cycle energy [22], and the building envelope is accountable for a significant share of embodied impacts. Consequently, alternative building options must be carefully assessed in new dwellings and, again, a life-cycle assessment study to support decision-making at an early building design stage is desirable.

Some studies covered South European dwellings [14,21,23-27]. However, a trend regarding which life-cycle phase has the most impact in new houses located in South Europe under a mild climate was not determined. Embodied and operational impacts are both significant, but their life-cycle contributions appear to be highly sensitive to construction options, energy systems, operation/occupation behavior, and regional aspects. The electric production mix (share of renewable) is essential to characterize the environmental impacts of the use phase $[14,28,29]$. Additionally, operational heating and cooling behavior can significantly affect a study outcome $[23,30]$.

Thus, the prevailing strategies for cold climate houses should not be directly transposed onto other building or climatic contexts [31] because, depending on the local context, the embodied impact may surpass the operational impact. Studying alternative passive architecture measures and their influence on operational energy of buildings in Spain, a recent study [32] concluded that, for some climate regions, a few passive strategies could reduce operational energy to the passive house level: north-south orientation, small window-to-wall ratio $(<20 \%)$, insulated envelope $\left(\mathrm{U}=0.35 \mathrm{~W} / \mathrm{m}^{2} \mathrm{~K}\right)$. Nevertheless, the authors recognize that user behavior remains unaddressed. Furthermore, as a life-cycle perspective was not considered, the embodied energy of the building measures was not assessed.

In South-Western Europe, many houses are exposed to a moderate Mediterranean warm climate, and interior comfort (operational patterns) may be dependent on user behavior (influenced by cultural heating habits and economic constraints). Thus, typical operational energy levels of these houses are lower than in most North and Central European countries [28]. According to Lavagna et al. [10], a considerable part of the environmental life-cycle impacts of EU building stock is associated with single family houses located in moderate climates, and new houses in this climate have not been widely assessed considering user behavior.

Regarding building components, exterior walls comprise a significant part of the construction embodied impact [29,33], and roofs were also identified as significant [34], especially for top-floor dwellings. A recent life-cycle study has assessed 114 flat roof alternatives for a Portuguese apartment 
located in Lisbon considering environmental, energy, and economic criteria [34]. The functional unit assessed was $1 \mathrm{~m}^{2}$ of roof used during a 50-year lifetime. The study concluded that, with an identical insulation layer, the roof impacts can vary widely among alternatives (e.g., the best non-accessible roof can lower $\mathrm{CO}_{2}$ emissions by $30 \%$ ).

The goal of this study is to assess the life-cycle environmental influence of key building envelope options (with varying thermal performance) for a South-Western European compact house located in Portugal in a moderate Mediterranean climate. This research investigates how operational and embodied impacts of a house vary with building envelope alternatives in order to identify the alternatives with the lowest impacts. LCA and building dynamic simulation were integrated to assess the following envelope construction options throughout the walls and roof: five insulation thickness levels $(0-12 \mathrm{~cm})$, four total ventilation levels $(0.3-1.2 \mathrm{ac} / \mathrm{h})$, and six insulation materials. In addition, since exterior walls represent most of the building envelope area, three exterior wall construction alternatives (double brick, concrete, and wood walls) were also considered.

\section{Materials and Methods}

LCA methodology [35] was used to assess the environmental impact of building envelope alternatives for a new South-Western European house located in a mild Mediterranean warm climate in Coimbra, Central Portugal (1460 heating degree days). An attributional LCA approach [36] was selected since it was not expected that the flows within the supply chains would change as a consequence of the adoption of the alternatives assessed. A process-based life-cycle inventory was built based on previous research $[23,28,37]$ and using average background data. The functional unit selected was to build and use a house (for a 4-person family) during its lifespan. A lifespan of 50 years was assumed since it is a common lifespan considered for buildings in the literature [8,37]. The life-cycle study included three life-cycle phases: construction, operation (heating and cooling), and maintenance of the building and envelope alternatives. Furthermore, these phases are considered the most significant and amount to the majority of a building's life-cycle impacts (82-98\%, based on [16]).

The construction phase included material production, transport to the construction site, and on-site construction processes (considering a $5 \%$ material waste factor). Materials and techniques commonly used in Portugal during the last few decades were assumed. The environmental impacts of building material production and transport were aggregated by average construction product or process and assessed based on European background data from ecoinvent v3.2 [38], using SimaPro 8.3 software [39].

Maintenance activities that preserve the physical characteristics of the building during its lifespan (painting, vanishing, and roof water-proof layer replacement) were taken into account based on data from local construction material producers $[40,41]$. Detailed information regarding the maintenance activities schedule can be found in [28]. Their environmental impact was assessed based on background data from ecoinvent v3.2.

The annual heating and cooling loads for the house and the various building alternatives were obtained by thermal simulation in DesignBuider (C) v3.0 [42], which is a dynamic thermal simulation tool based on the Energyplus calculation engine (tested and validated under the comparative standard method of test BESTEST and ANSI/ASHRAE Standard 140-2011). Operational patterns were considered to better represent mild climate modest energy (heating and cooling) use, typical of Portuguese dwellers. In the LCA, the heating and cooling electric energy requirements obtained by thermal simulation were converted to life-cycle environmental impacts using inventory data for the Portuguese electricity generation mix in 2012 [43]. In the last few years, Portugal has consistently had a large share of electricity generated from renewable energy sources when compared to other European countries, which influences the operational life-cycle impact.

Information regarding the case study definition, namely construction and alternative construction scenarios considered, can be found in Section 2.1, while operational phase details and the operational patterns considered are presented in Section 2.2. 
In the life-cycle impact assessment (LCIA) stage, two well-known LCIA methods were used. These were the cumulative energy demand (CED) method, to account for the non-renewable primary energy (NRPE), and the CML 2001 method, to account for the following environmental impacts [44]: abiotic depletion, global warming potential (GWP), acidification, eutrophication, photochemical oxidation, and ozone layer deletion (OLD).

Given the comparative nature of this LCA study, the life-cycle model implemented assumed a few simplifications, which are identified and explained in Table 1.

Table 1. Life-cycle model simplifications.

\begin{tabular}{|c|c|}
\hline $\begin{array}{l}\text { Simplifications and } \\
\text { Processes Out of the Scope }\end{array}$ & Reason \\
\hline Energy used on construction site & It is considered of minor importance in other studies $[1,45]$. \\
\hline $\begin{array}{l}\text { Furniture, plumbing, sanitary equipment, heat } \\
\text { distribution pipes, change in land use }\end{array}$ & $\begin{array}{l}\text { These are not affected by the alternative building envelope } \\
\text { options and do not affect the comparative nature of the } \\
\text { findings. Hence, embodied impacts are underestimated in } \\
\text { the life-cycle model. }\end{array}$ \\
\hline Appliances and domestic hot water use, lighting & $\begin{array}{l}\text { These needs are not dependent on envelope options. } \\
\text { Improvements are independent of the building and mainly } \\
\text { related to available technology (appliances efficiency) and } \\
\text { user behavior. }\end{array}$ \\
\hline $\begin{array}{l}\text { Insulation materials' thermal properties were } \\
\text { assumed to remain the same throughout the lifespan }\end{array}$ & $\begin{array}{l}\text { Though the EU standards recommend considering the } \\
\text { aging process of construction products to estimate the } \\
\text { decay of thermal properties, overtime was out of the scope } \\
\text { of our study. }\end{array}$ \\
\hline End-of-life phase & $\begin{array}{l}\text { Expected to have a small life-cycle magnitude, representing } \\
\text { less than } 4 \% \text { in Mediterranean dwellings (Nemry et al., } \\
\text { 2010). Additionally, to predict waste treatment scenarios } \\
\text { for such distant future (50 years) encompasses high } \\
\text { uncertainty and waste treatment processes can change. }\end{array}$ \\
\hline
\end{tabular}

\subsection{Construction: Base Case House and Envelope Alternatives}

The house under study is a Portuguese household occupied by a 4-person family. A single-family house was selected because it is the most common residential building type in Portugal. The compact building shape, typology, and area are representative of an average Portuguese house based on statistical data [46,47]: it has two floors, $133 \mathrm{~m}^{2}$, and a 3-bedroom typology. Table 2 describes the main building components of the base case house; axonometric drawings of the building can be found in [37].

Table 2. Base case house building components description.

\begin{tabular}{|c|c|c|c|}
\hline Building Component & Area $\left(m^{2}\right)$ & Units & Description \\
\hline Roof & 74.4 & & $\begin{array}{l}\text { Gravel }(0.05 \mathrm{~m}) \text {; polypropylene felt; extruded } \\
\text { polystyrene }(\mathrm{XPS}) \text { insulation }(0.06 \mathrm{~m}) \text {; bitumen } \\
\text { layer }(0.005 \mathrm{~m}) \text {; anhydrite screed }(0.05 \mathrm{~m}) \text {; } \\
\text { reinforced concrete slab }(0.15 \mathrm{~m}) \text {; lime mortar } \\
(0.02 \mathrm{~m}) ; \mathrm{U}=0.39 \mathrm{~W} / \mathrm{m}^{2} \mathrm{~K} .\end{array}$ \\
\hline Slab & 76.4 & & $\begin{array}{l}\text { Wooden flooring }(0.04 \mathrm{~m} \text { square joists, air-layer, } \\
0.02 \mathrm{~m} \text { planks); anhydrite screed }(0.03 \mathrm{~m}) \text {; } \\
\text { reinforced concrete slab }(0.15 \mathrm{~m}) \text {; lime mortar } \\
(0.02 \mathrm{~m}) .\end{array}$ \\
\hline Ground floor & 80 & & $\begin{array}{l}\text { Wooden flooring }(0.04 \mathrm{~m} \text { square joists, air-layer } \\
\text { XPS) } 0.02 \mathrm{~m} \text { planks); lightweight anhydrite } \\
\text { screed }(0.05 \mathrm{~m}) \text {; reinforced concrete }(0.12 \mathrm{~m}) \text {; } \\
\text { gravel }(0.20 \mathrm{~m}) \text { on ground; } \mathrm{U}=0.56 \mathrm{~W} / \mathrm{m}^{2} \mathrm{~K} \text {. }\end{array}$ \\
\hline
\end{tabular}


Table 2. Cont.

\begin{tabular}{|c|c|c|c|}
\hline Building Component & Area $\left(m^{2}\right)$ & Units & Description \\
\hline Structure & & & $\begin{array}{l}\text { Beams, columns, foundations: } \\
\text { reinforced concrete }\end{array}$ \\
\hline Exterior walls & 220 & & $\begin{array}{l}\text { Base plaster painted; hollow-brick masonry } \\
(0.11 \mathrm{~m}) \text {; air-cavity with XPS }(0.06 \mathrm{~m}) \text {; } \\
\text { hollow-brick masonry }(0.15 \mathrm{~m}) \text {; base plaster; } \\
\text { painting; } \mathrm{U}=0.33 \mathrm{~W} / \mathrm{m}^{2} \mathrm{~K} .\end{array}$ \\
\hline Interior walls & 110 & & $\begin{array}{l}\text { Hollow-brick masonry }(0.11 \mathrm{~m}) \text {; base plaster } \\
(0.02+0.02 \mathrm{~m}) \text {; painting. }\end{array}$ \\
\hline Windows & 1 & 11 & $\begin{array}{l}\text { Aluminum-frame with thermal break; } \\
\text { double-glazing } \mathrm{U}=1.1 \mathrm{~W} /\left(\mathrm{m}^{2} \mathrm{~K}\right) \text {; exterior } \\
\text { plastic shutters }\end{array}$ \\
\hline Doors (interior) & 1.6 & 8 & Wooden doors, varnished. \\
\hline Exterior door & 2 & 1 & Wooden doors, varnished $\left(\mathrm{U}=1.8 \mathrm{~W} /\left(\mathrm{m}^{2} \mathrm{~K}\right)\right.$. \\
\hline
\end{tabular}

A parametric analysis of the alternative construction options studied (presented in Table 3) was performed for the following: five envelope insulation levels $(0-12 \mathrm{~cm})$, five insulation materials, four total ventilation levels (including infiltration), and three exterior wall systems.

Table 3. Envelope construction alternatives and base case.

\begin{tabular}{|c|c|c|c|c|}
\hline Passive Construction & \multicolumn{3}{|c|}{ Alternatives Studied } & Base Case \\
\hline $\begin{array}{c}\text { Envelope extruded } \\
\text { polystyrene (XPS) } \\
\text { insulation level }(\mathrm{cm}){ }^{1,2}\end{array}$ & \multicolumn{3}{|c|}{$0 ; 3 ; 6 ; 9 ; 12$} & 6 \\
\hline $\begin{array}{l}\text { Total ventilation level, } \\
\text { including infiltration } \\
\qquad(\mathrm{ac} / \mathrm{h})^{1}\end{array}$ & \multicolumn{3}{|c|}{$0.3 ; 0.6 ; 0.9 ; 1.2$} & 0.6 \\
\hline \multirow[t]{2}{*}{$\begin{array}{c}\text { Exterior wall } \\
\text { construction type }\end{array}$} & $\begin{array}{c}\text { Double } \\
\text { hollow-brick } \\
\text { masonry } \\
\text { (XPS insulation) }\end{array}$ & $\begin{array}{l}\text { Concrete block } \\
\text { masonry }^{2} \\
\text { (EPS insulation) }\end{array}$ & $\begin{array}{c}\text { Wood walls } \\
\text { (XPS insulation) }\end{array}$ & $\begin{array}{c}\text { Double } \\
\text { hollow-brick } \\
\text { masonry } \\
\text { (XPS insulation) }\end{array}$ \\
\hline & 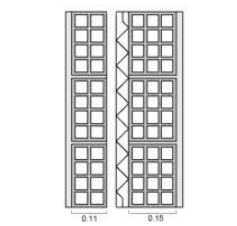 & (1) & (n) & 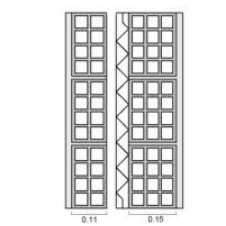 \\
\hline $\begin{array}{c}\text { Insulation material } \\
{ }^{1} \text { (equivalent } U \text {-value) }\end{array}$ & \multicolumn{3}{|c|}{$\begin{array}{l}\text { XPS; XPS } \mathrm{CO}_{2} ; \mathrm{EPS} ; \text { Cork; Polyurethane rigid foam (PUR); } \\
\text { Rock wool }\end{array}$} & XPS \\
\hline
\end{tabular}

A hypothetical non-insulated scenario $(0 \mathrm{~cm})$, which does not meet the legal thermal requirements, was considered with the sole purpose of better showing how operational and embodied impacts vary with the insulation level (i.e., allowing us to draw in results figures which are representative of the polynomial trend-line from $0 \mathrm{~cm}$ through the following insulation thicknesses). Nevertheless, in the analysis, a focus is given to insulated alternatives $(3-12 \mathrm{~cm})$.

\subsection{Building Operational Conditions}

Operational energy consumption is directly affected by the building characteristics and by the construction options studied. The operational phase included the impact of heating and cooling the 


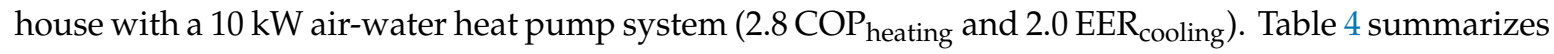
the energy building simulation settings used to assess the house with alternative building construction alternatives in DesignBuider (C) v3.0. A window-shutter schedule, presented in Table 5, was assumed to account for typical use of the window-shutters to benefit from solar gains during the heating season and avoid them during cooling season.

Table 4. Building simulation settings, OP100.

\begin{tabular}{|c|c|}
\hline Building Simulation Settings & Description \\
\hline \multicolumn{2}{|l|}{ 3D build-up model } \\
\hline Living area $\left(\mathrm{m}^{2}\right)$ & 133.2 \\
\hline Conditioned volume & 360 \\
\hline $\begin{array}{l}\text { Heating set-point air temperature } \\
\text { (with no set-back) }\end{array}$ & $20^{\circ} \mathrm{C}$ \\
\hline $\begin{array}{l}\text { Cooling set-point air temperature } \\
\text { (with no set-back) }\end{array}$ & $25^{\circ} \mathrm{C}$ \\
\hline $\begin{array}{l}\text { Heating Ventilation and Air Conditioning } \\
\text { (HVAC)schedule; gains schedule }\end{array}$ & 0:00-24:00 (24 $\mathrm{h} / 7$ a year $)$ \\
\hline Location & Coimbra, Portugal \\
\hline Latitude/longitude $\left({ }^{\circ}\right)$ & $40.2^{\circ} /-8.4^{\circ}$ \\
\hline Elevation above sea $(\mathrm{m})$ & 140 \\
\hline Hourly weather data & PRT_Coimbra_IWEC \\
\hline Internal gains (lumped into a single value) & $4 \mathrm{~W}$ per $\mathrm{m}^{2}$ of living area; as recommended by [48] \\
\hline Air-tightness (infiltration) & Dependent on total ventilation scenario \\
\hline Gains schedule & 0:00-24:00 (24 h/7 a year $)$ \\
\hline
\end{tabular}

Table 5. Window shading schedule.

\begin{tabular}{cccc}
\hline Annual Period & Days & Shutters Open & Shutters Closed (Shading) \\
\hline \multirow{2}{*}{ 30 September to 30 June } & weekdays & $7 \mathrm{~h}-19 \mathrm{~h}$ & $19 \mathrm{~h}-7 \mathrm{~h}$ \\
& weekends & $9 \mathrm{~h}-19 \mathrm{~h}$ & $19 \mathrm{~h}-9 \mathrm{~h}$ \\
\hline \multirow{2}{*}{ 30 June to 30 September } & weekdays & $7 \mathrm{~h}-8.5 \mathrm{~h}$ & $8.5 \mathrm{~h}-7 \mathrm{~h}$ \\
& weekends & $9 \mathrm{~h}-12 \mathrm{~h}$ & $12 \mathrm{~h}-9 \mathrm{~h}$ \\
\hline
\end{tabular}

A continuous operational pattern (OP100) that reflects continuous interior comfort conditions and occupation (identified in Table 3) was initially used to thermally assess the residential building performance. However, in mild climates, users do not heat and cool continuously, nor do they heat all the rooms simultaneously. Due to this fact, the final energy results were significantly higher when compared to statistical data on energy consumption in Portuguese houses. For instance, comparing the thermal energy requirements for an equivalent existing house with identical shape/construction (based on Portuguese building stock characteristics [47]) and the average real heating energy consumption 
per square meter in houses in Portugal (inferred from statistical data; [49]), a continuous operational pattern reveals a significant gap $[9,28]$. Portuguese real household consumption can be $75 \%$ lower than simulated energy needs for maintaining continuous comfort conditions. This gap, called the prebound effect [30], represents the way in which user behavior can reduce expected energy consumption levels. It seems that Portuguese dwellers heat their homes partially, or at cooler temperatures, or have their heating on for less time than assumed in the simulated continuous operational pattern. This is possible because winter climate conditions are not as harsh as in North and Central European locations and the summer climate is not hot but warm. Furthermore, occupants tend to use heating more economically in houses that are thermal underperformers [30,50]. Consequently, the prebound effect percentage might change with the thermal performance of the building, decreasing the benefit of energy efficiency measures. As real operational energy consumption data are limited, in this LCA study, two alternative operational pattern scenarios were used to inform heating and cooling habits:

- OP25, which represents a low occupancy and modest and partial heating and cooling level, reinforced by Portuguese statistical data; it holds $25 \%$ of the energy requirements of simulated continuous operational pattern.

- OP50, which assumes the average occupancy of a working-out family and medium heating and cooling level, holding $50 \%$ of the simulated heating and cooling energy requirements for OP100.

This study did not intend to assess the specific effect of dynamic (zoned and intermittent) operational patterns, which widely vary with the household. Stazi et al. [51] covered these aspects and the effect of thermal mass (inertia) in three super-insulated multifamily buildings both for hot and cold climates. They concluded that, in such highly insulated envelopes, thermal mass had a low influence on operational energy savings (marginal benefit). Additionally, thermal mass (masonry alternative) had a stronger effect on comfort levels (less discomfort hours for intermittent cooling) but it had $20 \%$ higher environmental life-cycle impacts (for ecoindicator' 99 ).

\section{Results}

The main LCA results are presented for two operational patterns (OP25 and OP50). Firstly, the influence of alternative ventilation and insulation levels was assessed for the base case house (house with double hollow-brick walls and double-glazing windows, using heat pump system). Later, the influence of alternative exterior wall systems and insulation level were assessed. Lastly, alternative insulation materials were considered. When assessing alternative insulation levels, trend-lines (polynomial, order 4) are shown in the figures to clearly indicate the influence of varying insulation levels from a hypothetical $0 \mathrm{~cm}$ insulation.

\subsection{Influence of Ventilation Level vs. Insulation Level}

Four total ventilation levels $(0.3-1.2 \mathrm{ac} / \mathrm{h})$ and five insulation levels $(0-12 \mathrm{~cm})$ were considered for the base case house. Life-cycle results are presented for non-renewable primary energy (NRPE) in Section 3.1.1. and for six environmental impact categories in Section 3.1.2.

\subsubsection{Non-Renewable Primary Energy}

The construction phase of insulated house alternatives $(3-12 \mathrm{~cm})$ was the most important phase (Figure 1) in terms of life-cycle NRPE, representing 63-82\% in OP25 and 49-76\% in OP50, whereas the operational phase represented $8-28 \%$ and $14-43 \%$ of NRPE in OP25 and OP50, respectively. Insulation thickness tipping-points, for which NRPE was reduced, were identified: these were $3-6 \mathrm{~cm}$ for OP25 and 6-9 $\mathrm{cm}$ for OP50. However, in OP50, the total life-cycle benefit of having more insulation than $6 \mathrm{~cm}$ was less than $1 \%$ for all ventilation scenarios. The insulation tipping-point did not change significantly with the ventilation level. 


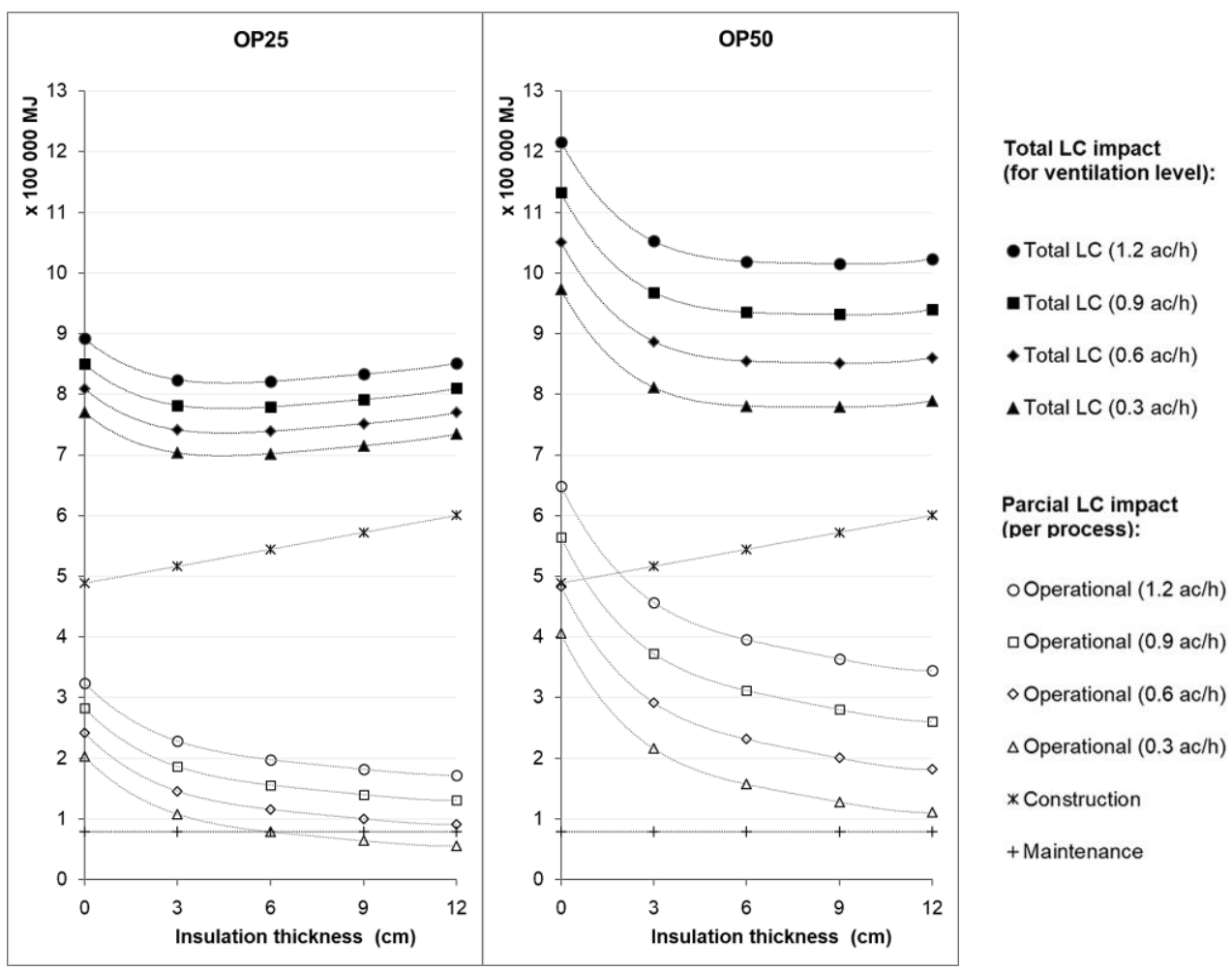

Figure 1. NRPE results for base case house with a heat pump for OP25 and OP50: ventilation level vs. insulation level.

In a well-insulated $(6 \mathrm{~cm})$ and air-tight $(0.3 \mathrm{ac} / \mathrm{h})$ house with modest energy use (OP25), maintenance had a similar impact to operational energy. When operational energy is reduced, other life-cycle phases' relative contributions are increased.

Compared with a hypothetical non-insulated house $(0 \mathrm{~cm}, 1.2 \mathrm{ac} / \mathrm{h}), \mathrm{a} 6 \mathrm{~cm}$ XPS layer reduced operational NRPE by 39-61\% (from OP25 to OP50) but it only achieved a life-cycle reduction of $8-9 \%$ (OP25) or 16-20\% (OP50). Lowering the overall ventilation level from 1.2 to $0.3 \mathrm{ac} / \mathrm{h}$ reduced operational NRPE by 38-68\% (from OP25 to OP50) and life-cycle NRPE by $14-15 \%$ (OP25) or 20-23\% (OP50). Assessing the joint effect of the measures ( $6 \mathrm{~cm}$ insulation; $0.3 \mathrm{ac} / \mathrm{h}$ ventilation), maximum NRPE reductions of $21 \%$ (OP25) and 36\% (OP50) were achieved compared to the hypothetical worst scenario. The base case house $(6 \mathrm{~cm} ; 0.6 \mathrm{ac} / \mathrm{h})$ yielded a 17\% (OP25) and a 30\% (OP50) NRPE reduction.

\subsubsection{Environmental Impact Assessment}

LCIA results are presented for OP25 (Figure 2) and OP50 (Figure 3) to determine whether a broader environmental impact assessment results in the same conclusions as the NRPE analysis. Results show that abiotic depletion, acidification, and GWP correlate with NRPE (Figure 1). In OP25, the insulation tipping-point was between 3 and $6 \mathrm{~cm}$ for most categories (exceptions: eutrophication and OLD), whereas in OP50, the tipping-point varied widely: 3-6 cm for GWP and photochemical oxidation; 9-12 cm for abiotic depletion and acidification. For eutrophication, the tipping-point was above $12 \mathrm{~cm}$ even in OP25, since the insulation material used (XPS) had relatively low impact in this category. Regarding OLD, the impact of construction (87-99\%) surpassed, by far, operational impacts in insulated alternatives. Construction materials, especially XPS insulation, had a significant contribution to OLD. The high impact of XPS is justified by the extrusion process that uses a hydrofluorocarbon (HFC-134a). 


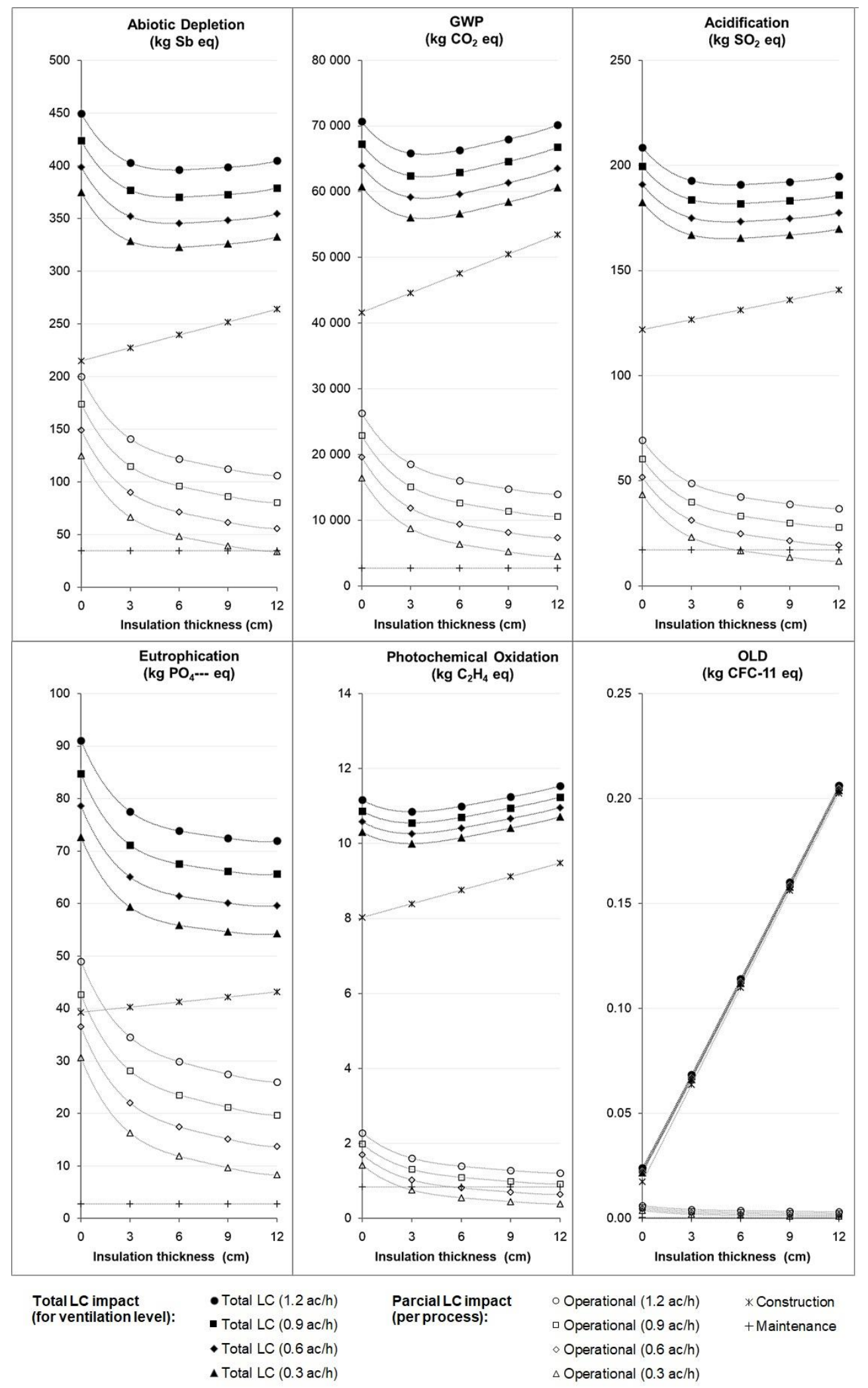

Figure 2. LCIA results for base case house with a heat pump for OP25: ventilation level vs. insulation level. 


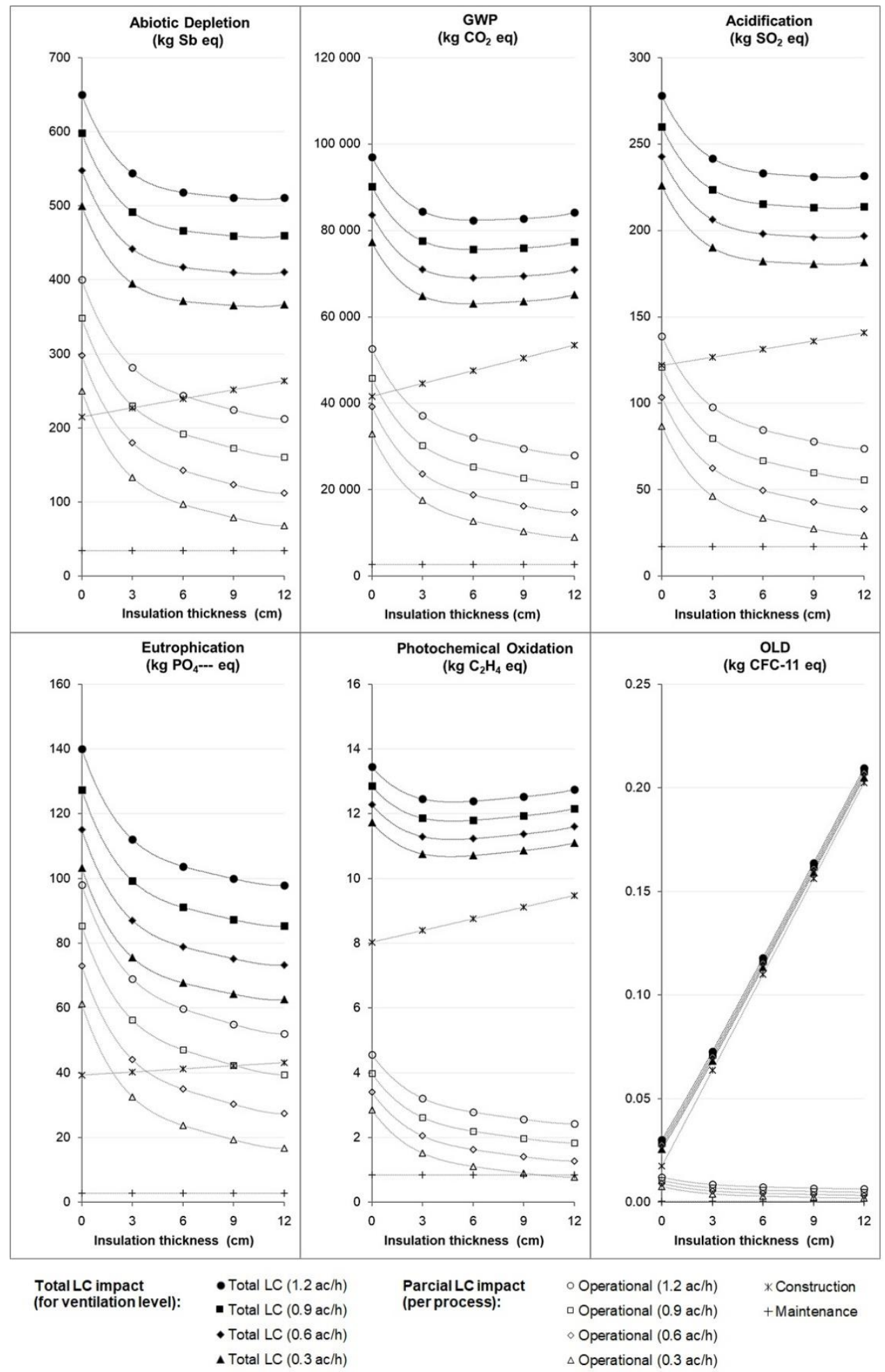

Figure 3. LCIA results for base case house with a heat pump for OP50: ventilation level vs. insulation level.

In OP25, construction was the most significant life-cycle phase for all categories in insulated house alternatives. Furthermore, in photochemical oxidation, construction had a significant impact (77-88\%). In OP50, the most significant phase (construction or operation) varies with the insulation and ventilation levels. For the house with two simple passive construction measures $(6 \mathrm{~cm}$ XPS and $0.6 \mathrm{ac} / \mathrm{h}$ ), embodied impacts had a life-cycle contribution above $67 \%$. 


\subsection{Influence of Exterior Wall Construction Alternatives vs. Insulation Level}

In this subsection, three exterior wall alternatives-double brick, lightweight concrete, and wooden wall-were assessed jointly with different envelope insulation levels. Results are presented for the base case house with $0.6 \mathrm{ac} / \mathrm{h}$ ventilation level.

\subsubsection{Primary Energy}

Figure 4 presents NRPE for OP25 and OP50. Results show that the operational energy of the three exterior wall house alternatives is similar and mostly dependent on the envelope insulation level. Embodied energy (NRPE) surpassed operational energy for all insulated alternatives, amounting to $62-78 \%$ in OP25 and $52-70 \%$ in OP50, whereas operation varied from $12 \%$ to $25 \%$ in OP25 and $21 \%$ to $40 \%$ in OP50.

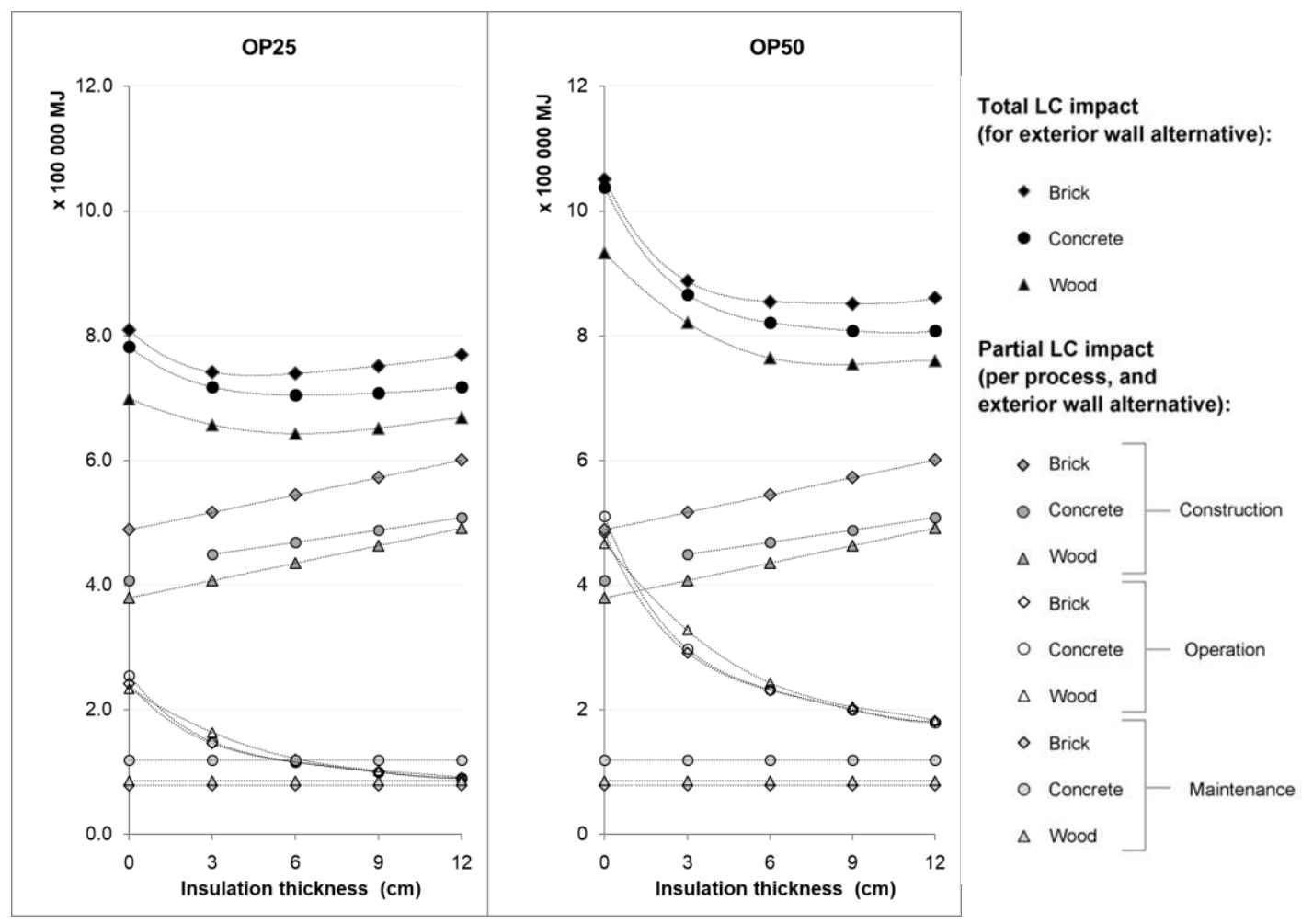

Figure 4. NRPE for OP25 and OP50 for exterior wall house alternatives (brick, concrete, and wood) vs. insulation level.

The double brick wall construction had the highest embodied energy. Comparatively, the concrete wall construction alternative had 13-15\% lower embodied NRPE (depending on insulation level), and the wood wall alternative had $22-18 \%$ lower embodied NRPE. In the CED method, wood is considered a renewable source of energy and has low embodied NRPE. Thus, the wood wall house had the lowest NRPE, with a reduction of 11-14\% (OP25) or 7-11\% (OP50) NRPE when compared with the base case brick house. The concrete wall house had a NRPE reduction of 3-7\% (OP25) or 1-6\% (OP50) since the embodied energy reduction was partially offset by the higher maintenance requirements. Maintenance of a concrete wall house results in a higher NRPE than the other exterior wall alternatives, mainly due to the acrylic plaster finishing of ETICS (exterior thermal insulation composite system).

The insulation tipping-point varied both with the exterior wall alternative and with the operational patterns. For OP25, tipping-points were $6 \mathrm{~cm}$ for concrete and wood wall houses and $3 \mathrm{~cm}$ for the base case brick house. For OP50, the tipping-points were around $12 \mathrm{~cm}$ for concrete wall, $9 \mathrm{~cm}$ for wood wall, and $6 \mathrm{~cm}$ for brick wall house. 


\subsubsection{Environmental Impact Assessment}

Figures 5 and 6 present the LCIA results for OP25 and OP50, respectively. Acidification closely correlates with NRPE. Abiotic depletion had a slightly higher operational relative contribution. Other environmental categories present some differences in the life-cycle phase contributions, insulation tipping-points, and specific insulation material impacts.

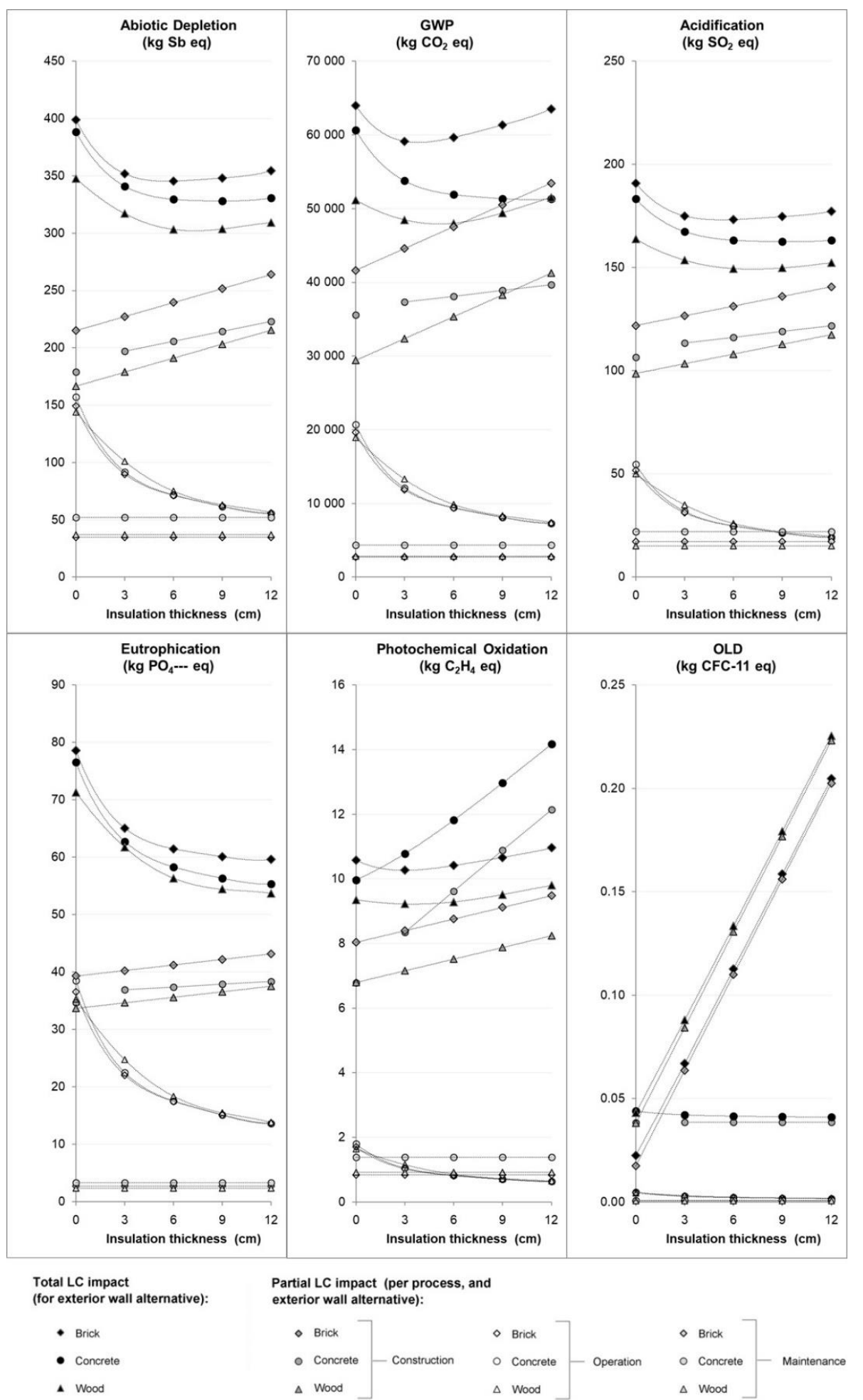

Figure 5. LCIA house results for OP25: exterior wall construction alternatives vs. insulation level. 


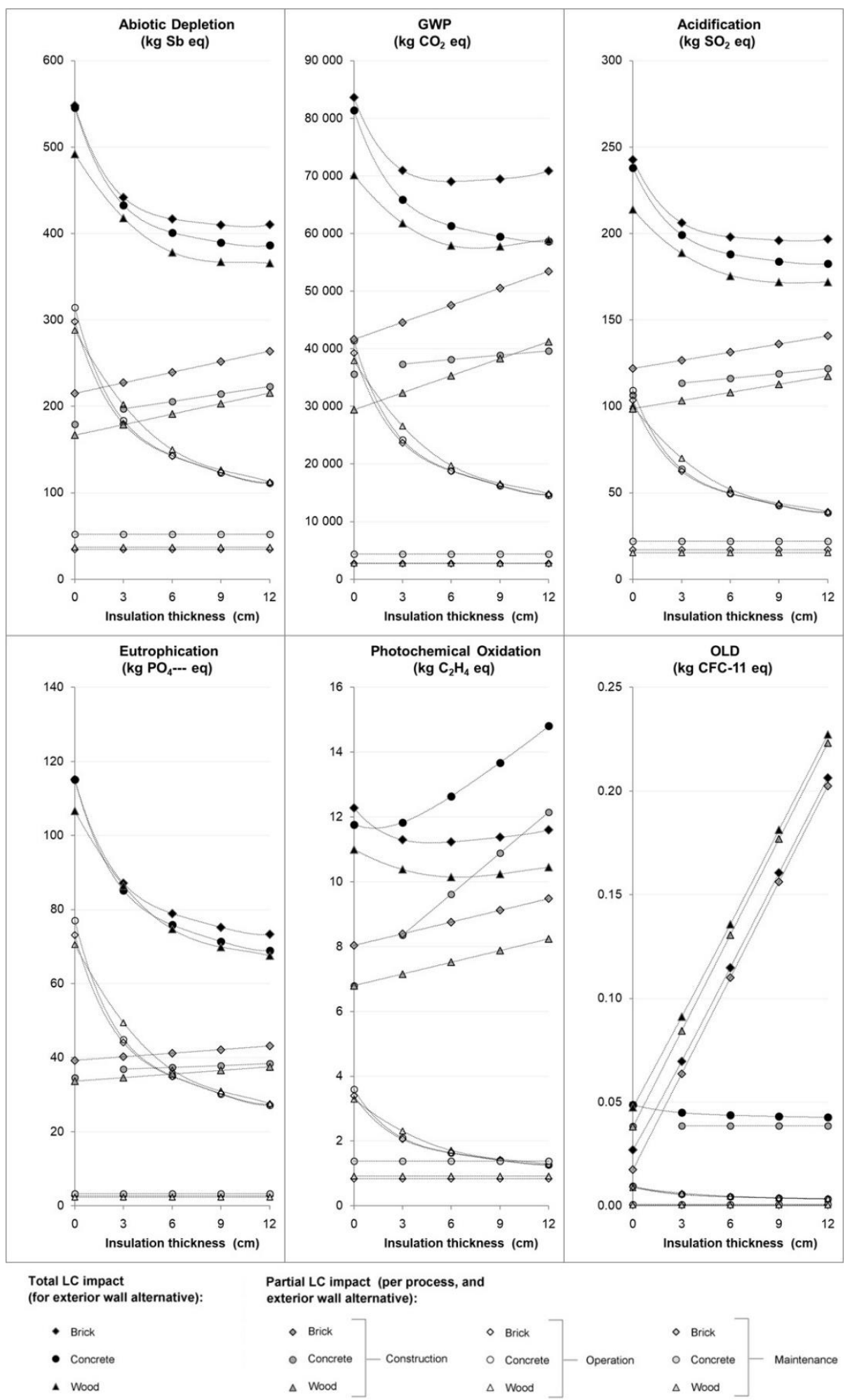

Figure 6. LCIA house results for OP50: exterior wall construction alternatives vs. insulation level.

In GWP, photochemical oxidation, and OLD, dissimilar embodied impacts are associated with XPS (brick and wood walls) and EPS (concrete wall ETICS). XPS had a 3.8 times higher GWP impact and 2000 times higher OLD impact than EPS for the same insulation thickness, whereas EPS had a 3.5 times higher photochemical oxidation impact than XPS. The OLD impact magnitude of XPS insulation is due to HFC-134a being used during the extrusion process, as explained in Section 3.2.1. 
The insulation thickness tipping-point varied with exterior wall alternative, operational patterns, and impact categories. In OP25, the tipping-points for most environmental categories were as follows: between 3 and $6 \mathrm{~cm}$ for the brick wall alternative and $6 \mathrm{~cm}$ for wood wall alternative (exceptions: eutrophication, OLD); for the concrete wall, it was above $12 \mathrm{~cm}$ for three categories (GWP, eutrophication, OLD), $9 \mathrm{~cm}$ for abiotic depletion and acidification, and $0 \mathrm{~cm}$ for photochemical oxidation. Results show that the acrylic plaster finishing of ETICS had a high photochemical oxidation impact that surpasses operational energy savings due to insulation. In OP50, the tipping-points for both the brick and the wood wall were as follows: nearly $6 \mathrm{~cm}$ for GWP and photochemical oxidation; $9-12 \mathrm{~cm}$ for abiotic depletion and acidification; above $12 \mathrm{~cm}$ for eutrophication. The tipping-points for the concrete wall alternative were above $12 \mathrm{~cm}$ for five categories, except for photochemical oxidation.

Comparing the three exterior wall alternatives, the double brick wall had the highest embodied and total life-cycle impacts in four categories (abiotic depletion, GWP, acidification, eutrophication). Wood wall construction was the alternative with the lowest impacts in five categories, presenting a reduction of $7-20 \%$ in contrast to the brick wall alternative. In OP25, the embodied impacts of construction held most of the life-cycle impact in all environmental categories for insulated house alternatives. In OP50, the same was valid in four categories (except in abiotic depletion and eutrophication).

Assuming a $6 \mathrm{~cm}$ insulation level, which is a likely insulation level for a new house, the construction phase accounts for most of the house life-cycle impacts both in OP25 and OP50. In OP25, construction amounts to $62-84 \%$ of life-cycle impacts, operation $7-33 \%$, and maintenance accounted for $5-16 \%$ in five categories (except OLD, which is explained below). Meanwhile, in OP50, construction accounted for $48-78 \%$ of life-cycle impacts, operation $13-49 \%$, and maintenance accounted for $3-13 \%$. OLD is a particular category in which embodied impacts were responsible for almost all impacts (88-98\%), especially in the wall alternatives that incorporated XPS insulation (96-98\% of life-cycle impacts), as explained in Section 3.2.1.

\subsection{Influence of Insulation Material}

To assess the specific influence of the selected insulation material, Table 6 presents how the embodied impact of the construction stage of the house varies with alternative insulation materials. The insulation materials' thicknesses were defined to have an equivalent insulation level to the base case house, which means that the building envelope delivers the same U-values of the base case (with $6 \mathrm{~cm}$ XPS).

Table 6. Influence of alternative insulation materials on the life-cycle impacts of the house compared to the base case house (XPS insulation).

\begin{tabular}{ccccccccc}
\hline $\begin{array}{c}\text { Insulation } \\
\text { (Thermal Conductivity } \\
\left.\text { W/m } \mathbf{m}^{2} \mathbf{K}\right)\end{array}$ & NRPE & AD & GWP & AP & EP & PO & OLD \\
\hline XPS CO 2 & 0.035 & $1.4 \%$ & $1.4 \%$ & $-7.4 \%$ & $-0.5 \%$ & $0.2 \%$ & $3.2 \%$ & $-96.9 \%$ \\
EPS & 0.038 & $3.5 \%$ & $3.6 \%$ & $-6.4 \%$ & $0.9 \%$ & $-0.2 \%$ & $45.4 \%$ & $-96.9 \%$ \\
Cork & 0.038 & $-6.8 \%$ & $-6.3 \%$ & $-10.4 \%$ & $-1.1 \%$ & $-0.5 \%$ & $-3.3 \%$ & $-96.9 \%$ \\
PUR & 0.04 & $1.3 \%$ & $0.7 \%$ & $-6.4 \%$ & $3.2 \%$ & $14.0 \%$ & $4.4 \%$ & $-96.7 \%$ \\
Rock Wool & 0.025 & $-1.7 \%$ & $-2.1 \%$ & $-7.9 \%$ & $0.1 \%$ & $2.0 \%$ & $-3.1 \%$ & $-97.0 \%$ \\
\hline No insulation $^{2}$ & 0.035 & $-10.4 \%$ & $-10.3 \%$ & $-12.7 \%$ & $-7.3 \%$ & $-5.6 \%$ & $-8.0 \%$ & $-97.0 \%$ \\
\hline
\end{tabular}

${ }^{1}$ The base case XPS thermal conductivity was $0.030 \mathrm{~W} / \mathrm{m}^{2} \mathrm{~K} ;{ }^{2}$ The non-insulation scenario allows us to account for the embodied impact of base case thermal insulation.

Results clearly show that changing the insulation material from XPS to cork panels can reduce the house embodied impact in the construction stage in all categories while ensuring the same operational impact. In fact, if cork insulation is considered, comparing the embodied with the operational LC impact (presented for alternative insulation levels in previous figures), the cork thickness tipping-point 
for the brick house would be between $12 \mathrm{~cm}$ (for OP25) and $16 \mathrm{~cm}$ (for OP50), being able to reduce the overall life-cycle NRPE by around 5.6-7.8\% (in OP25-OP50). Results show that cork insulation is preferred compared to the other materials; the only downside would be the higher space that it takes to ensure the same performance (e.g., to ensure the same envelope U-value, cork insulation must be 1.33 times thicker than base case XPS).

\section{Discussion}

This study's results reinforce the idea that LCA is crucial not only to avoid problem-shifting but also to identify the most significant life-cycle processes, materials, and hotspots for improvement in new houses. Additionally, they highlight that under mild South European climates (e.g., Coimbra) and in the Portuguese context, even a lightly insulated house can have higher embodied impacts than the operational (for heating and cooling), whereas a new house (base case with $6 \mathrm{~cm}$ and 0.6 ac/h) is likely to have more embodied impacts in all environmental impact categories.

This finding may be surprising when compared to other studies, even for South European houses (Table 7), because both user behavior and climate widely vary. For instance, Italy and Spain are South European countries but they may have higher heating requirements or higher cooling requirements than houses in temperate, warm, summer, Mediterranean climates (Csb Köppen-Geiger climate classification) depending on the specific location of the buildings studied. Furthermore, users may heat and cool their houses differently (continually or partially) and this was shown to affect the operational energy magnitude in this study. Thus, operational patterns should reflect patterns of inhabiting and acclimatizing a house (typical user behavior). Assessing operational patterns more intensively than actual consumption might result in higher embodied energy (than needed) and be counterproductive.

Table 7. Comparison of case study and literature life-cycle results for GWP.

\begin{tabular}{cccccc}
\hline & \multicolumn{4}{c}{ Life-Cycle GWP (kg CO $\mathbf{2} \mathbf{e q} / \mathbf{m}^{2}$.year) } \\
\hline Location & OP (C/P) & Operation HVAC & Construction & Maintenance & Total \\
\hline Spain, Barcelona [14] & $\mathrm{C}$ & $\begin{array}{c}1.7 \text { heating } \\
10.7 \text { cooling }\end{array}$ & 4.5 & 2.9 & 49.4 \\
\hline Spain, Zaragoza [26] & $\mathrm{C}$ & 10.2 HVAC & 10,3 & - & $25^{1}$ \\
\hline Spain, Lleida ${ }^{2}$ [27] & $\mathrm{C}$ & $\begin{array}{l}53.2 \text { heating } \\
21.1 \text { cooling }\end{array}$ & 60.5 & - & 134.8 \\
\hline Italy, Piedmont [21] & $\mathrm{C}$ & 0.78 HVAC & 10.8 & - & $17.4^{1}$ \\
\hline $\begin{array}{c}\text { Portugal, Coimbra: } \\
\text { base case house }\end{array}$ & $\mathrm{P}$ & $\begin{array}{l}2.5 \text { heating } \\
0.3 \text { cooling }\end{array}$ & 7.5 & 0.4 & 10.4 \\
\hline
\end{tabular}

Legend: OP (operational pattern): C—continuous; P—partial. ${ }^{1}$ Other operational energy needs were accounted for beyond heating and cooling; ${ }^{2}$ the case study is a house-like cubicle with similar construction to the base case.

Other reasons that may justify such differences are the following:

(a) Design-related: the fairly compact building, north-south oriented, with a low window-to-wall ratio. Some of these passive design measures were identified as being important to reduce operational energy in a Mediterranean climate [32]. Nevertheless, it would be interesting to assess the influence of different building designs for this climatic and operational context from a life-cycle perspective.

(b) The heavyweight building components (exterior and interior brick walls, concrete structure, roof and slabs) are known to incorporate high embodied impact (e.g., both brick and concrete production involve high energy consumption processes) [12,51];

(c) The high performance of the heating and cooling system adopted (heat pump). As shown in other studies, heating systems can play a key role in reducing environmental impacts [28,52]; 
(d) The Portuguese electricity mix, which has a substantial share of renewables [43]. In the last few years (and likely in the next few years), the electric mix should continue to have an increased contribution of renewable energy, which is expected to have lower environmental impact. Thus, it is even more likely that the operation phase has lower overall significance in new houses. Therefore, it is important to assess the embodied impacts in construction materials in order to arrive at construction alternatives with lower overall environmental impacts and consider those impacts at the project level jointly with operational environmental impacts at the local scale to avoid problem shifting.

Regarding the base case house, this study showed that reducing the ventilation level to $0.3 \mathrm{ac} / \mathrm{h}$ without compromising indoor air quality reduced life-cycle impacts by $4-14 \%$, while adopting an alternative wood wall construction instead of the brick one reduced LC impact by $7-20 \%$. These two measures are more beneficial passive solutions than increasing XPS insulation beyond $6 \mathrm{~cm}$ thickness, which only marginally reduced the overall impact (NRPE). Increasing insulation levels results in gradually lower NRPE savings and can even generate higher NRPE (when insulation is above the tipping-point), since embodied energy requirements offset operational energy savings.

This should hold true for new houses with a fairly compact shape and small window-to wall ratios, such as the base case, using a heat pump system, under similar climate conditions.

Operational impact was more affected by the insulation thermal resistance and thickness than by the varying construction of the exterior wall. This can be justified because all house alternatives had high thermal inertia, due to the heavyweight core of the house (concrete structure and brick interior walls), which remained unchanged. In this case, for the same insulation level, the life-cycle differences among exterior wall alternatives were mainly due to embodied impacts and maintenance procedures typical of different construction types.

The study also identified other material issues for improvement, namely the following:

(a) Cork insulation had the lowest life-cycle impacts when compared with other insulation materials;

(b) The base case XPS insulation had a high impact on OLD. This impact is justified by the extrusion process that used hydrofluorocarbons (HFC-134a). Recently, XPS producers started to use $\mathrm{CO}_{2}$ and acetone or HCF-152a as alternative blowing agents to replace HFC-134a. An LCA study of insulation materials [53] that assumed this replacement showed that new production methods can drastically reduce XPS OLD impact (from $1.64 \times 10^{-4}$ to $7.27 \times 10^{-8} \mathrm{~kg}$ CFC-11eq, per $\mathrm{kg}$ of XPS) and, in that case, the insulation tipping-point would be above the $12 \mathrm{~cm}$ thickness for both OP25 and OP50.

(c) The acrylic plaster used in ETICS concrete walls was associated with a high impact for photochemical oxidation, so alternative production methods for this finishing layer should be studied

\section{Conclusions}

An LCA of a house located in Coimbra (in mild, warm, Mediterranean climate) was performed, considering two operational patterns (OP25 and OP50). The influence of the following alternative building envelope options were assessed: insulation thickness levels $(0-12 \mathrm{~cm})$; ventilation levels (0.3-1.2 ac/h); insulation materials; exterior envelope solutions (double brick, concrete, and wood walls). The results showed that combining two simple passive construction measures, a good envelope insulation level $(6 \mathrm{~cm})$, and an air-tight envelope $(0.3 \mathrm{ac} / \mathrm{h}$ ventilation level) may lead to important LC primary energy savings of $21 \%$ (for OP 25 ) to $36 \%$ (for OP50) when compared to a hypothetical uninsulated house $(0 \mathrm{~cm} ; 1.2 \mathrm{ac} / \mathrm{h})$. Increasing the base case XPX insulation thickness has only marginal life-cycle benefits and can even increase the overall life-cycle impacts (depending on operational patterns). Thus, to avoid problem-shifting, LCA is critical to assess the balance between embodied and operational impact. Insulation tipping-points (with reduced life-cycle impact) were identified for the 
various environmental categories ranging between 3 and $6 \mathrm{~cm}$ for OP25 and 6 and $9 \mathrm{~cm}$ for OP50 for the brick wall house with XPS insulation.

Regarding the base case house (brick wall; $6 \mathrm{~cm} ; 0.6 \mathrm{ac} / \mathrm{h}$ ), two measures were identified to have more benefit than increasing XPS thickness: (a) the replacement of brick walls by wood walls (achieved a LC reduction of 7-20\%); (b) increases in envelope air-tightness and reductions in total ventilation level to $0.3 \mathrm{ac} / \mathrm{h}$ (achieved a LC reduction of $4-14 \%$ ). Regarding alternative insulations, cork panels resulted in the lowest embodied impact for an equivalent U-value envelope. Furthermore, for this material, the tipping-point thickness was around $12-16 \mathrm{~cm}$, and it enabled a reduction in the life-cycle NRPE impact of the base case house by around $5-8 \%$.

This study showed that construction represents a significant share (62-81\%) of the LC impacts of new houses with fairly simple construction measures, using a heat pump system to satisfy current modest Portuguese operational user demands. This is a surprising result alongside other comparable studies, especially of buildings in Mediterranean countries because LCA impacts are strongly influenced by the climate and cultural local conditions (how to build and inhabit a house) and energy mix. Embodied impacts are currently not routinely considered in building energy performance certification [54]. However, as new buildings are expected to be very low energy in operation, neglecting embodied impacts may lead to problem-shifting, having higher embodied impacts in upfront construction than the avoided impacts in operation.

Thus, the adoption of construction options with lower embodied impact is highly important. To further reduce the environmental impact of buildings under mild climates, data on the environmental impact embodied in materials should be freely available in the marketplace—for instance, through widespread environmental product declaration (EPD) or product environmental footprint (PEF) schemes. This would greatly benefit architects, engineers, and households as they take into account the environmental impacts of their decision-making. Finally, to assess the overall sustainability of a wide range of building alternatives, future research work should further examine building life-cycle costs at higher resolutions and a greater range of the associated social impacts.

Author Contributions: Conceptualization, H.M. and F.F.; methodology, formal analysis and investigation, visualization, writing — original draft preparation, funding acquisition: H.M.; writing-review and editing, H.M., F.F and J.E.F.; supervision, F.F., J.E.F. and H.M. All authors have read and agreed to the published version of the manuscript.

Funding: This work partially results from the funding that H.M. received from the Portuguese Fundação para a Ciência e a Tecnologia (SFRH/BD/33736/2009) and from the Energy for Sustainability (EfS) initiative from University of Coimbra.

Acknowledgments: H.M. acknowledges MIT Portugal Program and MIT for providing assistance and allowing H.M. to perform part of this research at the MIT Building Technology Lab.

Conflicts of Interest: The authors declare no conflict of interest. The funders had no role in the design of the study; in the collection, analyses, or interpretation of data; in the writing of the manuscript, or in the decision to publish the results.

\section{References}

1. Nemry, F.; Uihlein, A.; Colodel, C.M.; Wetzel, C.; Braune, A.; Wittstock, B.; Hasan, I.; Kreißig, J.; Gallon, N.; Niemeier, S.; et al. Options to reduce the environmental impacts of residential buildings in the European Union-Potential and costs. Energy Build. 2010, 42, 976-984. [CrossRef]

2. Invidiata, A.; Lavagna, M.; Ghisi, E. Selecting design strategies using multi-criteria decision making to improve the sustainability of buildings. Build. Environ. 2018, 139, 58-68. [CrossRef]

3. Göswein, V.; Rodrigues, C.; Silvestre, J.D.; Freire, F.; Habert, G.; König, J. Using anticipatory life cycle assessment to enable future sustainable construction. J. Ind. Ecol. 2019, 24, 178-192. [CrossRef]

4. Iribarren, D.; Marvuglia, A.; Hild, P.; Guiton, M.; Popovici, E.; Benetto, E. Life cycle assessment and data envelopment analysis approach for the selection of building components according to their environmental impact efficiency: A case study for external walls. J. Clean. Prod. 2015, 87, 707-716. [CrossRef] 
5. Chau, C.K.; Leung, T.; Ng, W. A review on life cycle assessment, life cycle energy assessment and life cycle carbon emissions assessment on buildings. Appl. Energy 2015, 143, 395-413. [CrossRef]

6. Cabeza, L.F.; Rincón, L.; Vilarino, V.; Pérez, G.; Castell, A. Life Cycle Assessment (LCA) and life cycle energy analysis (LCEA) of buildings and the building sector: A review. Renew. Sustain. Energy Rev. 2014, 29, 394-416. [CrossRef]

7. Karimpour, M.; Belusko, M.; Xing, K.; Bruno, F. Minimising the life cycle energy of buildings: Review and analysis. Build. Environ. 2014, 73, 106-114. [CrossRef]

8. Buyle, M.; Braet, J.; Audenaert, A. Life cycle assessment in the construction sector: A review. Renew. Sustain. Energy Rev. 2013, 26, 379-388. [CrossRef]

9. Soares, N.; Bastos, J.; Pereira, L.D.; Soares, A.R.; Amaral, A.; Asadi, E.; Rodrigues, E.; Lamas, F.; Monteiro, H.; Lopes, M.; et al. A review on current advances in the energy and environmental performance of buildings towards a more sustainable built environment. Renew. Sustain. Energy Rev. 2017, 77, 845-860. [CrossRef]

10. Lavagna, M.; Baldassarri, C.; Campioli, A.; Giorgi, S.; Valle, A.D.; Castellani, V.; Sala, S. Benchmarks for environmental impact of housing in Europe: Definition of archetypes and LCA of the residential building stock. Build. Environ. 2018, 145, 260-275. [CrossRef]

11. Gustavsson, L.; Joelsson, A. Life cycle primary energy analysis of residential buildings. Energy Build. 2010, 42, 210-220. [CrossRef]

12. Tokbolat, S.; Nazipov, F.; Kim, J.; Karaca, F. Evaluation of the environmental performance of residential building envelope components. Energies 2019, 13, 174. [CrossRef]

13. Hossain, Y.; Marsik, T. Conducting Life Cycle Assessments (LCAs) to determine carbon payback: A case study of a highly energy-efficient house in rural Alaska. Energies 2019, 12, 1732. [CrossRef]

14. Ortíz-Rodriguez, O.O.; Castells, F.; Sonnemann, G. Life cycle assessment of two dwellings: One in Spain, a developed country, and one in Colombia, a country under development. Sci. Total Environ. 2010, 408, 2435-2443. [CrossRef]

15. Rodrigues, C.; Freire, F. Environmental impact trade-offs in building envelope retrofit strategies. Int. J. Life Cycle Assess. 2016, 22, 557-570. [CrossRef]

16. Rasmussen, F.N.; Ganassali, S.; Zimmermann, R.K.; Lavagna, M.; Campioli, A.; Birgisdóttir, H. LCA benchmarks for residential buildings in Northern Italy and Denmark-Learnings from comparing two different contexts. Build. Res. Inf. 2019, 47, 833-849. [CrossRef]

17. Dylewski, R. Optimal thermal insulation thicknesses of external walls based on economic and ecological heating cost. Energies 2019, 12, 3415. [CrossRef]

18. Stephan, A.; Crawford, R.H.; De Myttenaere, K. A comprehensive assessment of the life cycle energy demand of passive houses. Appl. Energy 2013, 112, 23-34. [CrossRef]

19. Dodoo, A.; Gustavsson, L.; Sathre, R. Lifecycle carbon implications of conventional and low-energy multi-storey timber building systems. Energy Build. 2014, 82, 194-210. [CrossRef]

20. Kylili, A.; Ilic, M.; Fokaides, P.A. Whole-building Life Cycle Assessment (LCA) of a passive house of the sub-tropical climatic zone. Resour. Conserv. Recycl. 2017, 116, 169-177. [CrossRef]

21. Blengini, G.; Di Carlo, T. The changing role of life cycle phases, subsystems and materials in the LCA of low energy buildings. Energy Build. 2010, 42, 869-880. [CrossRef]

22. Dodoo, A.; Gustavsson, L.; Sathre, R. Life cycle primary energy implication of retrofitting a wood-framed apartment building to passive house standard. Resour. Conserv. Recycl. 2010, 54, 1152-1160. [CrossRef]

23. Monteiro, H.; Freire, F. Life-cycle assessment of a house with alternative exterior walls: Comparison of three impact assessment methods. Energy Build. 2012, 47, 572-583. [CrossRef]

24. Bastos, J.; Batterman, S.A.; Freire, F. Life-cycle energy and greenhouse gas analysis of three building types in a residential area in Lisbon. Energy Build. 2014, 69, 344-353. [CrossRef]

25. Sierra-Pérez, J.; Boschmonart-Rives, J.; Gabarrell, X. Environmental assessment of façade-building systems and thermal insulation materials for different climatic conditions. J. Clean. Prod. 2016, 113, 102-113. [CrossRef]

26. Bribian, I.Z.; Uson, J.A.A.; Scarpellini, S. Life cycle assessment in buildings: State-of-the-art and simplified LCA methodology as a complement for building certification. Build. Environ. 2009, 44, 2510-2520. [CrossRef] 
27. Llantoy, N.; Chàfer, M.; Cabeza, L.F. A comparative Life Cycle Assessment (LCA) of different insulation materials for buildings in the continental Mediterranean climate. Energy Build. 2020, 225, 110323. [CrossRef]

28. Monteiro, H.; Fernández, J.E.; Freire, F. Comparative life-cycle energy analysis of a new and an existing house: The significance of occupant's habits, building systems and embodied energy. Sustain. Cities Soc. 2016, 26, 507-518. [CrossRef]

29. Rossi, B.; Marique, A.-F.; Reiter, S. Life-cycle assessment of residential buildings in three different European locations, case study. Build. Environ. 2012, 51, 402-407. [CrossRef]

30. Sunikka-Blank, M.; Galvin, R. Introducing the prebound effect: The gap between performance and actual energy consumption. Build. Res. Inf. 2012, 40, 260-273. [CrossRef]

31. Gaspar, P.; Santos, A.L. Embodied energy on refurbishment vs. demolition: A southern Europe case study. Energy Build. 2015, 87, 386-394. [CrossRef]

32. Fernandez-Antolin, M.-M.; Del Río, J.M.; Costanzo, V.; Nocera, F.; Gonzalez-Lezcano, R.A. Passive design strategies for residential buildings in different Spanish climate zones. Sustainability 2019, 11, 4816. [CrossRef]

33. Monteiro, H.; Freire, F. Environmental life-cycle impacts of a single-family house in Portugal: Assessing alternative exterior walls with two methods. Gazi Univ. J. Sci. 2011, 24, 528-534.

34. Jean, S.-S.; Lee, P.-I.; Hsueh, P.-R. Treatment options for COVID-19: The reality and challenges. J. Microbiol. Immunol. Infect. 2020, 53, 436-443. [CrossRef] [PubMed]

35. ISO. ISO 14044: Environmental Management_Life Cycle Assessment_Requirements and Guidelines; International Organization of Standardization: Geneva, Switzerland, 2006.

36. Weidema, B.P.; Pizzol, M.; Schmidt, J.; Thoma, G. Attributional or consequential Life Cycle Assessment: A matter of social responsibility. J. Clean. Prod. 2018, 174, 305-314. [CrossRef]

37. Monteiro, H. Comprehensive Life Cycle Assessment of New Houses in Portugal: Building Design, Envelope, and Operational Conditions. PhD Thesis, Faculty of Sciences and Technology of University of Coimbra (FCTUC), Coimbra, Portugal, 2017.

38. Wernet, G.; Bauer, C.; Steubing, B.; Reinhard, J.; Moreno-Ruiz, E.; Weidema, B.P. The ecoinvent database version 3 (part I): Overview and methodology. Int. J. Life Cycle Assess. 2016, 21, 1218-1230. [CrossRef]

39. PRé Sustainability SimaPro. Available online: https://simapro.com/about/ (accessed on 7 February 2020).

40. Kellenberger, D.; Althaus, H.-J.; Jungbluth, N.; Künniger, T.; Lehmann, M.; Thalmann, P. Life Cycle Inventories of Building Products; Final Report Ecoinvent Data v2.0 No.7; Ecoinvent: Dübendorf, Switzerland, 2007.

41. Künzel, H.; Künzel, H.M.; Sedlbauer, K. Long-term performance of external thermal insulation systems (ETICS). Archit. Z. Für Gesch. Der Baukunst 2006, 5, 11-24.

42. DesignBuider (C, version 3.0; DesignBuilder Software Ltd.: London, UK, 2017.

43. Garcia, R.; Marques, P.; Freire, F. Life-cycle assessment of electricity in Portugal. Appl. Energy 2014, 134, 563-572. [CrossRef]

44. Hischier, R.; Weidema, B.; Althaus, H.-J.; Bauer, C.; Doka, G.; Dones, R.; Frischknecht, R.; Hellweg, S.; Humbert, S.; Jungbluth, N.; et al. Implementation of Life Cycle Impact Assessment Methods Data v2.2.; Ecoinvent Rep. No. 3; Ecoinvent: Dübendorf, Switzerland, 2010; Volume 176.

45. Gervásio, H.; Santos, P.; Martins, R.; Da Silva, L.S. A macro-component approach for the assessment of building sustainability in early stages of design. Build. Environ. 2014, 73, 256-270. [CrossRef]

46. INE. PORDATA Housing Confort and Living Conditions. Available online: https://www.pordata.pt/en/ Subtheme/Portugal/Accommodation-53 (accessed on 20 September 2002).

47. INE. O Parque Habitacional e a sua Reabilitação-Análise e Evolução 2001-2011; LNEC, Ed.; INE: Lisboa, Portugal, 2013; ISBN 978-989-25-0246-5.

48. RCCTE. Regulamento das Características de Comportamento Térmico dos Edifícios (Code of the Buildings Thermal Behaviour Characteristics); DL: Lisboa, Portugal, 2006; pp. 2468-2513.

49. INE-I.P./DGEG. Inquérito ao Consumo de Energia no Sector Doméstico 2010; INE: Lisboa, Portugal, 2011.

50. Galvin, R.; Sunikka-Blank, M. Economic viability in thermal retrofit policies: Learning from ten years of experience in Germany. Energy Policy 2013, 54, 343-351. [CrossRef]

51. Stazi, F.; Tomassoni, E.; Bonfigli, C.; Di Perna, C. Energy, comfort and environmental assessment of different building envelope techniques in a Mediterranean climate with a hot dry summer. Appl. Energy 2014, 134, 176-196. [CrossRef]

52. Pineau, D.; Rivière, P.; Stabat, P.; Hoang, P.; Archambault, V. Performance analysis of heating systems for low energy houses. Energy Build. 2013, 65, 45-54. [CrossRef] 
53. Pargana, N.; Pinheiro, M.D.; Silvestre, J.D.; De Brito, J. Comparative environmental life cycle assessment of thermal insulation materials of buildings. Energy Build. 2014, 82, 466-481. [CrossRef]

54. Toftum, J.; Baxter, V. Nearly-zero energy buildings. Sci. Technol. Built Environ. 2016, 22, 883-884. [CrossRef] 